\title{
Die kentering in die kultuurbeeld van die Ossewa-Brandwag, 1939-1940
}

\author{
P.J.J. Prinsloo \\ Departement Geskiedenis \\ Potchefstroomse Universiteit vir $\mathrm{CHO}$ \\ Vaaldriehoekkampus \\ VANDERBIJLPARK
}

\begin{abstract}
The change in the cultural image of the Ossewa-Brandwag, 1939-1940

In this article the cultural activities of the Ossewa-Branctwag (OB) are reviewed against the background of the expansion of Afrikaner nationalism. The founding enthusiasm of the $O B$ was essentially an indication to supporters that the anvakening of the nation as a result of the Voortrekker centenary festivisies: found their manifestation in the movement.

The aim of the $O B$ was therefore defined as the country-wide unifying of all Afrikaners, driven by patriotism to uphold the traditions of the nation towards the protection and promotion of the spiritual life of the nation.

This founding ain and aspiration of the movement was influenced by various factors: the $O B$ had, for example, been outspokenly republican and also developed as a political force since + Seplember 1939. Afier this date, the movement, having been stamped as a cultural organization since its foundation, began to display a militant protest character.

As of Seprenber 1939 the self-imposed cullural aims of the $O B$ have to be viewed as a means to a political end.
\end{abstract}

\section{Inleiding}

Die Ossewa-Brandwag (OB) wou in die tydperk van kol. J.C.C. Laas se kommandant-generaalskap 'n beduidende rol in die Afrikaner se kultuurontwikkeling vervul. Hierdie artikel handel derhalwe oor 'n periode in die $\mathrm{OB}$ se geskiedenis waarin die beweging se kultuurtaak deur verskeie ontwikkelingsfases gekenmerk is. Gedurende bogenoemde periode wou die beweging onder meer die kultuurorganisering val die Afrikaners op 'n nut geformuleerde wyse beliggaam (Prinsloo, 1983).

Die kultuuraktiwiteite van die $O B$ moet egter teen die breër agtergrond van ontwikkelings in die tydperk 1933 tot 1941 gesien word, aangesien verskeie faktore soos uiteenlopende ideologiese strominge in Afrikanergeledere gedurende 
die laat dertiger en vroeg veertigerjare, asook gebeure bui'e en binne Suid-Afrika, die ontplooiing van Afrikanernasionalisme beïnvlnrú hit.

\section{Ideologiese strominge en gebeure wat die ontplooiing van Afrikaner-nasionalisme beïnvloed het}

Verskeie uiteenlopende ideologiese strominge het in die onderhawige tydperk in Afrikanergeledere geheers. Een van die strominge was die ontwikkeling van 'n geslote, konserwatiewe Afrikanernasionalisme. Die Eeufeesherdenking van die Groot Trek in 1938 het die ontwikkeling van 'n eksklusiewe Afrikanernasionalisme bevorder, wat volgens die voorstanders van dié denkrigting tot die beswil van die volksgroep se totale volksontwikkeling moes strek. Hierdie stroming was veral gekant teen die bevordering van 'n oop, liberale, inperialistiese stroming, wat Suid-Afrika nouer aan die Britse Gemenebes wou koppel (Van der Scliyff, 1991:6-9).

Die Unie se toetrede tot die Europese oorlog op 4 September 1939 het, in die lig van bogenoemde twee wedywerende ideologiese strominge, 'n bitter politieke stryd ontketen. In die proses het 'n derde stroming waarneembaar geword: die aanhangers van Nasionaal-sosialisine het die sukses van die stelsel in Duitsland bewonder en nagevolg (Vatcher, 1965:58-63).

Bogenoemde ideologiese strominge het tot gevolg gehad dat die verskillende organisasies en verenigings, soos die $\mathrm{OB}$, Federasie van Afrikaanse Kultuurvereniginge (FAK), Afrikaanse Nasionale Kultuurraad, Reddingsdaadbond (RDB), Afrikaner-Broederbond, asook politieke partye soos die Verenigde Party, die Gesuiwerde Nasionale Party en sy opvolger die Herenigde Nasionale Party of Volksparty (HNP of V), uiteenlopende standpunte gehuldig het oor die wyse waarop hierdie volksgroep se volksontwikkeling georganiseer en uitgeleef moes word. Die gevolg was dat verskillende beleidsrigtings en kultuurpatrone in Afrikanergeledere ontwikkel het. Die soeke na 'n daadkragtige en rigtinggewende organisasie wat die Afrikanervolksgroep kon lei, het die noodsaak van omvattende kultuurorganisering beklemtoon.

In multikulturele samelewings, soos in Suid-Afrika, is dit noodsaaklik om in dié verband ook tussen 'n nasionale kultuurbeeld en subkulture of subkulturele groepe te onderskei (Beals, 1977:29; Steward, 1955:47). Hierdie opvatting impliseer dat die Afrikaner 'n subkulturele segment van die nasionale kultuur van Suid-Afrika uitmaak (Butler, 1961:9). In 'n artikel soos hierdie wat oor die Afrikaner handel, kan daar egter van 'n nasionale kultuurbeeld van die Afrikaner gepraat word en vorm die OB 'n subkulturele groep van die nasionale kultuurkomponent van die Afrikaner. 
In dié artikel word die plek en rol van die $\mathrm{OB}$ teen die agtergrond van die nasionale kultuurkomponent van die Afrikaner beoordeel. Dit is daarom ook nodig om kennis te neem dat daar met die stigting van die $O B$ reeds Afrikanerorganisasies op nasionale vlak gefunksioneer het. Die stigting van die FAK in Desember 1929 het in die behoefte van 'n landswye kultuurorganisasie voorsien wat na die Afrikaner se volkslewe moes omsien (Swart \& Geyser, 1979:14, 34). Die hoofdoel van die FAK was juis om alle Afrikaanse kultuur- en aanverwante verenigings saam te snoer. Die behoefte om die uitgebreide aktiwiteite van die FAK meer doeltreffend te hanteer, het in 1936 gelei tot die stigting van 'n breë oorkoepelende nasionale bestuursliggaam, die Afrikaanse Nasionale Kultuurraad. Hierdie bestuursliggaam het in 1938 'n uitgebreide program van aksie geloods. Die strategie kan as 'n doelbewuste poging gesien word om die sowat 230 verenigings in 'n omvattende organisasie te omskep (INEG, I.M. Lombard-versameling, lêer $8 / 4 / 1 / 1 / 1$, s.a.; leer $2 / 3 / 1 / 1 / 1$, s.a.).

Ten spyte van bogenoemde inisiatief in die geledere van die Afrikanerorganisasies, het die $\mathrm{OB}$ uit die staanspoor sy eiesoortige vertolking aan die beoefening van kultuuraktiwiteite vir die volksgroep geheg. Hoewel die $\mathrm{OB}$ se planne in wese met die doelstellings van bestaande kultuurorganisasies ooreengestem het, het die $O B$ in 'n opponerende gees doelbewus onafhanklik opgetree. Die $\mathrm{OB}$ se leiersfigure wou 'n nuwe daadkragtiger beweging in Afrikanergeledere vestig.

Die ontwikkelingsfase van die OB se geskiedenis wat in hierdie artikel ter sprake is, is ook gestimuleer deur 'n breër geestelike stroming wat in daardie stadium in Afrikanergeledere aanwesig was. Hierdie stroming was die ideologiese soeke na identiteit wat gesetel was in die ideaal om Afrikanervolkseenheid te bewerkstellig, asook die omvattende volksaksie om dié volksgroep se belange ooreenkomstig eie volksaard te ontwikkel (Cronjé, 1963:32; Moodie, 1975:x, 177).

Gedurende hierdie tydperk is die ontwikkeling van 'n aktiewe, meelewende volksgevoel in Afrikanergeledere op 'n sonderlinge wyse deur verskeie faktore en omstandighede teweeggebring. In hierdie opsig het die Voortrekkereeufeesviering die kultuurbelewenis van baie Afrikaners positief beinvloed. Hierdie feesviering het onder meer die grondslag vir 'n kulturele ontwaking in Afrikanergeledere gelê. Die Tweede Wêreldoorlog en die gepaardgaande oorlogtydse omstandighede in Suid-Afrika het hierdie kulturele ontwaking verpolitiseer en die hernieude volksgevoel in Afrikanergeledere tot die uiterste beproef.

Die gebeure buite en bimne Suid-Afrika het daarom nuwe uitdagings aan organisasies in Afrikanergeledere gestel. Die kultuurbeeld van die $O B$ wat in hierdie artikel aan die orde gestel is, het gevolglik in een van die gebeurtenisrykste tydperke in die geskiedenis van die Afrikanervolk plaasgevind (Die 
Burger, 1957-01-30). In die ontplooiing van die tema word vervolgens verskeie ontwikkelingsfases aangetoon, wat inderwaarheid deur opeenvolgende gebeure teweeggebring is

\section{Die kiemgedagte en stigting van die $\mathbf{O B}$}

Die kiemgedagte van die OB lê nie in die Eeufeesjaar nie, maar in maatreëls om die Unie se Engelsgeoriënteerde verdedigingsmag te verafrikaans. Sedert 1935 is 'n beweging vir dié doel onder Vrystaatse Afrikaanssprekendes in militêre kringe op dreef gebring (Prinsloo, 1983:16-19).

Die lewensvatbaarheid van die poging is vanaf 1937 verhoog - veral deur die ywer van kol. Laas. Laas is gedurende 1937 as die Vrystaatse organiserende stafoffisier vir Verdediging-Skietverenigings aangestel. Oswald Pirow, minister van Spoorweë, Hawens en Verdediging, het in wese 'n tweërlei doel met die aanstelling van 'n organiserende stafoffisier in die provinsies in gedagte gehad. Enersyds het hy hiermee die aktiewe herlewing van die kommandostelsel in die Burgermag ten doel gehad (Van der Walt, 1944:9, 10). Andersyds het hy die hoop gekoester dat die poging dieselfde dissiplineringsukses sou behaal as die Spesiale Diensbataljons wat op die lees van Hitler se jeugkampe geskoei was (Pirow, s.a.:219)

Laas het hierdie opdrag met oorgawe uitgevoer. Hy het onder die wakende oog van dr. J.F.J. (Hans) van Rensburg, die bevelvoerder van die 6de Brigade (OVS), die Verdediging-Skietverenigings van stapel gestuur. Op voorstel van Van Rensburg het hy ook uitgesoekte kemgroepe in elke skietvereniging as spesiale elite-seksies opgelei (Van Rensburg, 1956:156, 157).

Die ywerige kol. Laas het met geesdrif militêre kommandodae georganiseer waartydens militêre demonstrasies, militêre orkeste, toesprake en braaivleisfunksies aan die orde was. Laas het met entoesiasme van die kommandodae gepraat as 'n doelbewuste poging om die Afrikaner se volksliefde, volkstrots en volksbou te bevorder (Die Volksblad, 1937-09-22). Teen Mei 1938 het dr. Hans van Rensburg, die administrateur van die Vrystaat, verklaar dat die kommandodae wat deur Laas georganiseer is, die verbeelding van die Vrystaters so aangegryp het dat dit 'n belangrike faktor in die soeke na Afrikanervolkseenheid in dié provinsie geword het (The lriend, 1938-05-25).

Die besielde wyse waarop die Afrikaners die gedagte van die Ossewatrek ondersteun het - ' $n$ trek wat deur die Afrikaanse Taal- en Kultuurvereniging van die Suid-Afrikaanse Spoorweë en Hawens (ATKV) gereël is, het vir Laas 'n gulde geleentheid gebied om die organisering van kommandodae aan die Ossewatrek te verbind. Hy kon sy ideaal om die kommandotradisie te laat herleef 
gevolglik aan die Voortrekkereeufees koppel (OB-argief, H. van Rensburgversameling, band 4, lêer 35, 1938-09-07).

Laas se bydrae tot die Voortrekkereeufees het daarom gewentel om die organisering van kommando-erewagte, wat die waens van die Ossewatrek moes vergesel en beskerm (Van Rensburg, 1956:157). Die teenwoordigheid van kommando-erewagte was noodsaaklik omdat daar in Afrikanergeledere gevrees is dat persone wat die kultuuraksie vyandiggesind was, die waens tydens die feesvierings kon beskadig (Van Heerden, 1972:120-122).

Hierdie kommando-erewagte van uitgesoekte jongmanne kon volgens die besielde Laas as 'n volksleër gebruik word indien die stryd in Suid-Afrika weer tot geweld sou oorgaan. Sy sterk persoonlikheid het die jongmanne met hierdie idee van hom meegesleur (OB-argief, Onderhoude, Coetzee, bande 76, 77; Van Rensburg, bande 99, 100).

Van Rensburg het die stigting van sulke puik eenhede goed gevind (OB-argief, GR-stukke, Ossewa-Brandwag Jaarboek, 1949:7). Ten einde agterdog en teenkanting van die regering te voorkom, het Van Rensburg voorgestel dat Laas sy kommando-erewagte aan die feestelikhede van die Eeufeesvierings moes verbind en die kemgroepe Ossewa-Brandwagte moes noem. Hy het later die voorstel só in herinnering geroep. "At that moment the O.B. was, so to speak, brought to the baptismal font. Colonel J.C. Laas was the proud and indulgent father, and I was playing the godfather" (Van Rensburg, 1956:158).

Hierdie semi-militêr georiënteerde wyse waarmee Laas die Eeufeesaktiwiteite onderskraag het, het stellig die sukses van die reëlings rondom die Eeufeesvierings in die Vrystaat help verseker. In die proses het 'n algemene kulturele ontwaking in die provinsie tot stand gekom.

Die Ossewatrek en Eeufeesvierings het juis op 'n skouspelagtige wyse getoon dat daar meer geesdrif in 'n poging gelê het wat op daadwerklike wyse die volkseie tradisies gedemonstreer het. Dié Eeufeesvierings het die behoefte aan 'n organisasie wat die Afrikaner se kultuurgoedere op so 'n daadkragtige wyse blywend kon bevorder, opnuut aan die orde gestel (Prinsloo, 1983:24).

Bloemfonteiners het by twee geleenthede gedurende Oktober 1938 waens van die simboliese Ossewatrek op hul noordwaartse tog verwelkom (Mostert, 1940:381, 435; Kotzé, s.a.:3). By die geleenthede is die ideaal om 'n beweging te stig, wat die gees van die Eeufeesvierings in diens van die Voortrekkerideale sou bestendig, met erns bespreek (Van der Walt, 1944:11). Laas het ook sy ideaal vir bogenoemde Ossewa-Brandwagte verduidelik. Die trefkrag van hierdie ideaal het algemene byval gevind (Van Heerden, 1972:115), waarna 15 Bloemfonteinse Afrikaners gedurende die eerste week van November 1938 besluit het om 'n 
Die kentering in die kultumrbeeld van die Ossewa-Brandwag, 1939-1940

vereniging te stig wat as die Ossewa-Brandwag bekend sou staan (Van der Walt, 1944:169, 170).

Tydens die amptelike stigting van die OB op Saterdag 4 Februarie 1939 is die eerste offisiere van die Ossewa-Brandwag ingesweer. Hulle het plegtig 'n eed afgelê om nie te rus alvorens die vryheid van die Afrikanervolk herwin is nie. Die aflê van hierdie eed is ' $n$ duidelike bewys van die beweging se versluierde republikeinse ideaal, wat uit die staanspoor in die begrondingsmotief van die OB aanwesig was. Ds. C.R. Kotzé (voorsitter), mnr. N.G.S. van der Walt (sekretaris) en kol. Laas (leier en organiseerder) is as bestuurslede verkies (Van der Walt, 1944:9, 10).

Takke van die OB het soos paddastoele dwarsoor die land opgeskiet. Hierdie takke is in 'n semi-militêre organisasiestruktuur ooreenkomstig die kommandostelsel van die Voortrekkers georganiseer. Bestaande kultuurorganisasies is in takke van die $\mathrm{OB}$ omskep, selfs nog voordat die beweging behoorlik gepropageer is (OB-argief, N.G.S. van der Walt-versameling, Dagboek, 1944-04-30). Die behoefte om 'n vaste grondslag aan die beweging te gee, het daartoe gelei dat die bestuur in Julie 1939 'n konstitusie gepubliseer het (Van der Walt, 1944:13).

H.B. Thom was van mening dat daar seker nie nog 'n Afrikaanse beweging met soveel geesdrif en verwagting gestig is soos die Ossewa-Brandwag nie (Thom, 1980:99).

\section{Die grondslag en doel van die $O B$ gedurende die Laastydperk}

Die entoesiasme wat met die stigting van die $O B$ gepaard gegaan het, was vir OB-lede 'n aanduiding dat die volksontwaking, wat deur die Eeufeesvierings in Afrikanergeledere bewerkstellig is, sy beslag in die beweging gekry het (Prinsloo, 1983:27). Vir die OB-lede was hierdie eienskappe ook onmiskenbaar in hul eerste doelstellings aanwesig (OB-argief, Kommandant-generaal (KG)-stukke, Toespraak, 1941-09-11).

Die doelstellings van die beweging was daarom om alle Afrikaners wat deur volksliefde gedryf was, saam te snoer om die volkstradisies te handhaaf sodat die geestelike lewe van die volk beskerm en bevorder kon word (OB-argief, KGstukke, band 1, lêer 1, 1939-11-06).

Die funksies en werksaamliede van die beweging het sake soos die volgende ingesluit: die viering van Afrikaanse volksfeeste, die daarstelling van gedenktekens, kransleggings by monumente, die opspoor en instandhouding van geskiedkundige plekke, die reel van boeresportbyeenkomste met items soos skyfskiet en jukskeigooi, die beoefening van volkspele, die aanmoediging om volksliedjies te sing, die hou van optogte en byeenkoinste van opvoedkundige en 
P.J.J. Prinsloo

gesellige aard, toneelopvoerings, lesings oor die geskiedenis, die letterkunde en nasionale aangeleenthede, die wêreld van die vrou, debatte en die reël van kampe vir mans en vroue (Die Volksblad, 1939-02-06, 1939-04-22).

Ter realisering van hierdie ideale moes die $\mathrm{OB}$ as 'n landswye volksbrandwag vir Afrikanerbelange gevestig word. Die beweging het daarom 'n hoë premie op die vereniging van alle Afrikaners buite en bo die partypolitiek geplaas, om sodoende die volk na nuwe ontwikkelingsdoelwitte te lei (Die Volksblad, 1939-06-19).

Uit bogenoemde doelwitte is dit duidelik dat die $O B$ nie politiek as 'n begrondingseienskap van sy kulturele stelsel gesien het nie. Die OB het met nadruk verklaar dat dit nie 'n politieke organisasie was nie, maar 'n suiwer kulturele beweging (Die Volksblad, 1939-06-19).

Hierdie doelwitte is uit die staanspoor deur nie-OB-lede met agterdog en teenkanting bejeën (Van der Walt, 1944:18). Die Volkstem het die totstandkoming van die $O B$ as 'n mosie van wantroue in die bestaande kultuurliggame beskou (Die Volkstem, 1939-06-21). Dr. N.J. van der Merwe, die Vrystaatse Nasionale Partyleier (Van der Walt, 1944:21), asook die Kaapse Nasionale Partydagblad, Die Burger (Die Burger, 1940-04-09), het eweneens geoordeel dat die $\mathrm{OB}$ 'n oorbodige organisasie was wat net verdeeldheid op kultuurgebied kon veroorsaak. Die FAK, as leidinggewende kultuurkomponent van die Afrikaner se nasionale beweging, het na samesprekings met die OB-leiers nog steeds opponerend en skepties teenoor die beweging gestaan (INEG, I.M. Lombardversameling, lêer $1 / 3 / 2 / 1 / 1,1939-07-05$ ). Selfs die Afrikaner-Broederbond het op 'n kritiese wyse indringend oor die OB se doelwitte besin (OB-argief, N.G.S. van der Walt-versameling, 1939-05-10; Pelzer, 1979:177).

Het die $O B$ se doelwitte gerealiseer en kon die $O B$ ' $n$ staanplek in die Afrikanergeledere vestig? Die antwoord moet in die konteks van die gebeure na 4 September 1939 gesien word.

\section{Die realisering van die OB se kultuurdoelwitte}

Nouliks twee maande nadat die OB se konstitusie gepubliseer is, het die oorlogsdebat op 4 September 1939 in die Volksraad plaasgevind. Hierdie historiesgeworde datum in die Suid-Afrikaanse politiek was vir die OB 'n keerpunt in sy bestaan. Volgens G.D. Scholtz sou die $O B$ met sy kulturele doelwitte waarskynlik 'n vroeë dood gesterf het as dit nie was vir die wyse waarop Suid-Afrika in die Europese oorlog betrek is nie (Scholtz, 1974:160). Duisende Afrikaners het na die geleentheid gehunker om hul teenkanting teen die beleid van genl. Smuts te openbaar. Vir hierdie verset sou die OB hom uitmuntend leen, maar dit het ook die formulering van nuwe doelwitte tot gevolg gehad 
Die aktiwiteite van die $O B$ het inderdaad twee sye vertoon. Soos die sigbare gedeelte van 'n ysberg was die kultuurbeeld openbaar en vir almal waarneembaar. Vir baie Afrikaners was die $O B$ 'n kragdadige kultuurkrag wat moes besiel en dissiplineer, die Afrikaner se geesteskrag moes versterk en onderlinge verdeeldheid in die oorlogtydse omstandighede moes uitskakel (Thom, $1980: 100)$. Vir die kultuurnense in die OB was die invloed van die landspolitiek op die beweging ' $n$ beklaenswaardige ontwikkeling.

In dié tydperk het daar ook reeds 'n verborge polities-aktivistiese sy gestalte gekry (Fourie, 1987:25-29). Die OB was sedert 4 September 1939 uitgesproke republikeins en het as 'n politieke magsfaktor ontwikkel. Die OB het met sy rol van aktiewe verset teen die Unie se oorlogsdeelname, weerstand teen Smuts se sogenaamde anti-Afrikanerbeleid en stryd vir die behoud van die Afrikaner se belange, die kenmerke van 'n versetbeweging begin openbaar (OB-argief, Onderhoude, Botha, bande 160, 161; Stegmann, bande 135-137; Grobler, band 103; Roode, bande 168-171).

Die realisering van die $\mathrm{OB}$ se kultuurdoelwitte was in hierdie tweesydige dualisme vasgevang, wat deur die volgende uiteensetting geilllustreer word.

Die OB se geskiedkundige volksfeeste gedurende 1940 was kenmerkend van die nuwe kulturele daadkragtigheid wat die beweging wou vestig. Die Majubafees rondom 27 Februarie 1940 moes byvoorbeeld die eenheidsgevoel en durf in die beweging demonstreer. Die OB-lede uit die verskillende provinsies het daarom in lang motorstoete, met OB-vlaggies voorop die motors, na die berg Majuba opgetrek en fees gevier (OB-argief, Grootraadstukke (GR)-stukke, Korrespondensie, 1940-01-23; 1940-02-10).

In 'n poging om verdere daadkragtigheid te openbaar, het die beweging die plaas Majuba-Noord, waarop die berg Majuba geleë is, as volksbesit aangekoop. Die berg as nasionale gedenkwaardigheid is op 2 Januarie 1941 tydens 'n groot OBfees wat deur nagenoeg 20000 feesgangers bygewoon is, namens die Afrikanervolk in ontvangs geneem (OB-argief, GR-stukke, Notule, 1940-10-03). Hierdie fees het vir die $O B$ in die teken gestaan van sy daad- en eenheidskrag in Afrikanergeledere (Die Transvaler, 1941-01-02). Die onmiddellike betekenis van dié OB-kultuuraksie was dat Amajubadag voortaan as 'n volksfees in die ry van Afrikaanse feesdae toegevoeg is (Die Transvaler, 1941-01-03).

Tydens die Van Riebeeckfees op 6 April 1940 in Kaapstad het J.A. Smith 'n krans namens die $\mathrm{OB}$ gelê, as bewys dat die beweging die bakermat van die Afrikaner in herinnering geroep het (OB-argief, GR-stukke, Korrespondensie, 1940-04-02). Tydens die Heldedagfeesvierings op Bloemfontein het ds. C.R. Kotzé die OB-lede gemotiveer om volkshelde te eer, waana kranse op die grafte van pres. M.T. Steyn en genl. C.R. de Wet gelê is (Die Volksblad, 1940-10-12). 
P.J.J. Prinsloo

Die Wonderboomse Dingaansfeesviering van 15 en 16 Desember 1940 is deur koorsang, voordragte, ' $n$ erediens, toesprake en 'n erewag van jong OB's gekenmerk (OB-argief, M.S.F. Grobler-versameling, 1940-12-15, 16).

Hiernaas het die vele ander OB-byeenkonnste, wat deur groot getalle geesdriftige OB-lede bygewoon is, ook die kulturele sterkte van die beweging gereflekteer en die samehorigheidsgevoel tussen lede hegter gesmee. Jukskeispel, skyfskiet, toutrek, hoenderskop, piekniekspeletjies, skilpadtrek, beesvelgooi, volkspele, koorsang, voordragte en braaivleis was aan die orde tydens die gewilde en gesellige byeenkomste (The ('ape Argus, 1940-09-25; Die Burger, 1940-11-06).

Hoewel die uiterlike patroon van die OB-byeenkonste kulturele aktiwiteite beklemtoon het, het die sentrale tema van die toesprake baie duidelik die groter ideale van die beweging weerspieël. Die toespraaktemas het in hoofsaak gehandel oor die $O B$ se taak as onvattende beweging en die uitlewing van die Afrikaner se kulturele aspirasies en staatkundige verwagtinge. Hierdie temas is in feesvierings betrek om, volgens die redenaars, 'n stryd om die voortbestaan van die Afrikaner met 'n eie taal, kultuur, godsdiens en 'n vrye onafhanklike republiek te waarborg. Hierdeur wou die $\mathrm{OB}$, as vaderlandsliewende vrywillige korps, die Afrikaner aan elke front van die volkslewe saamsnoer en gereedmaak om vir sy voortbestaan te stry (Dic Burger, 1940-11-30, 1940-10-26).

Die vrouens en die jeug is ook gedurende 1940 op 'n hegter grondslag in die beweging georganiseer. Gedurende Oktober 1939 het Laas sy OB-kommandante opdrag gegee om oorspronklikheid en inisiatief aan die dag te lê en jeugklubs in hul afdelings te stig, waar volkspele en sang beoefen moes word (INEG, J.F. van der Merwe-versameling, lêer $2 / 2 / 1 / 1 / 1,1939-10-27)$. Teen die einde van 1940 is besluit om ook OB-penkopkommando's vir kinders onder 17 jaar in die lewe te roep. Elke kind wat wou aansluit, moes egter eers lid van die Voortrekkerbeweging geword het (OB-argief, GR-stukke, Notule, 1940-12-10, 11). Hierdie bepaling is ' $\mathrm{n}$ duidelike bewys dat die $O B$ in hierdie stadium nie bestaande Afrikanerorganisasies wou verlam nie. Die Jeugklubs en OB-penkopkommando's moes as onderafdelings van die $O B$ dieselfde doel en strewe as die moederliggaam nastreef. Die benaming Boerejeug is eers in Junie 1943 ingevoer.

Gedurende Junie 1940 het die organisering van vroue-afdelings ook vollediger beslag gekry. Vrouekommando's het apart van die mans se kommando's gefunksioneer en was verantwoordelik om saam met die mame die doelstellings van die $\mathrm{OB}$ uit te leef. Die OB-vroue is veral in 'n ondersteuningsrol aangewend. Hulle het opleiding in eerstehulp, gesondheidsleer, opvoedkundige vraagstukke, kantoorwerk, asook volksang en volkspele ontvang. Hulle was ook vir die versorging van huis en haard verantwoordelik, waarvoor deskundige voorligting aan hulle verskaf sou word. Tydens OB-byeenkomste was hulle vir die verversings verantwoordelik. Op dié wyse het die vroue 'n onontbeerlike rol in 
Die kemering in die kulmurbeeld van die Ossewa-Brandwag, 1939-19-10

die beweging se fondsinsamelingaksies vervul (OB-argief, GR-stukke, Korrespondensie, 1940-01-12; Onderhoude, Wagner, band 153).

Deur hierdie nuwe byvoegings tot die beweging wou die $O B$ al die kragte van die Afrikanerdom aanwend vir die bevordering van Afrikanerbelange (Die Burger, 1940-12-20).

Die $O B$ het ook die volksteater aangewend om die kultuunnilieu van die beweging te versterk. Teen ongeveer 1940 het Anna Neethling-Pohl, haar broer Jan en vier ander begaafde teaterpersoonlikhede die Katdoringtoneelgeselskap gestig. Hulle het die toneelgeselskap later tot ongeveer 18 lede uitgebrei. OBgesindes oor die lengte en breedte van die land is besiel deur hulle opvoerings, patriotiese gedigte en anti-oorlogsliedjies - opvoerings wat met groot geesdrif ontvang is (OB-argief, Onderhoude, Pohl, band 75; Robinson, band 43). Die Katdoringgeselskap het op hierdie wyse die digkuns, volksang en volksteater op 'n hartlike wyse, as bron van inspirasie en propaganda, in die beweging benut.

'n Verdere onderskeibare kultuurideaal van die OB in 1940 was die inskakeling en samesnoering van alle Afrikaners in die kultuumilieu van die beweging. Dit sou ook die $\mathrm{OB}$ se plek en rol in die Afrikaanse volksgemeenskap bepaal, omdat dit die omvang en statuur van die beweging as 'n omvattende volksbeweging sou versterk. Die Kaaplandse Beheerraad het byvoorbeeld twee doelwitte vermeld waardeur hierdie ideale verwesenlik kon word. Albei het betrekking gehad op die konsoliderings- of eenheidsverwagting, asook die gedissiplineerde en georganiseerde grondslag van die beweging.

Kragtens die eerste doelwit moes die $\mathrm{OB}$ alle Afrikaners verenig tot 'n goed georganiseerde en hegte volksgroep deur middel van volksfeeste en ander byeenkomste. Tydens die byeenkomste moes medeverantwoordelikheid by elke Afrikaner aangekweek word om op elke gebied van die volkslewe diensbaar te wees. Die eindresultaat van die kultuuraksies moes as volksdemonstrasies die volkseenheid, volkstrots en volkswil demonstreer (OB-argief, Gebiedsleidingstukke, s.a.: 1, 2).

In die tweede plek is gepoog om die OB se kulturele aktiwiteite ook op die geestelike terrein van die volkslewe te verbeter. Die OB wou deur middel van kerkparades hul gedissiplineerde aard gebruik om kerklosse Afrikaners weer as belydende lidmate in gemeentes te laat inskakel. Die kerke het nie die doelwit gesteun nie en dit was daarom nie suksesvol nie (Die Burger, 1940-09-25; The Sunday Times, 1940-11-24). Die OB het met groter sukses 'n VoortrekkerSondag en 'n Uniale Biddag georganiseer, wat deur elke lid van die beweging bygewoon moes word (OB-argief, GR-stukke, Notule, 1940-10-03). 
P.J.J. Prinsloo

Die $O B$ se gesondheidsafdeling wat vir noodhulp verantwoordelik was, het opleiding deur middel van die ATKV en die SA Noodhulpliga ontvang. Die opgeleide lede moes aan die hand van dié beweging se voorskrifte oor volksgesondheid en volksvoeding, as instrukteurs en instruktrises in die OB optree (OB-argief, Noodhulp, 1940-04-12, 1940-07-09).

Op ekonomiese vlak het die OB die RDB en die Boerenoodhulpfonds gesteun. Die OB het gedurende 1941, as gevolg van die arrestasie en internering van OBlede deur die regering, sy eie noodhulpfonds gestig (OB-argief, J. de W. Straussversameling, 1940-11-08; Die Burger, 1940-06-07).

Deur bogenoemde aktiwiteite het die OB nie net 'n kultuurdiens gelewer nie, maar ook gepoog om bestaande organisasies en bewegings op nasionale vlak te ondersteun. Hierdie ondersteuning het bestendigheid aan die $\mathrm{OB}$ se verhouding tot ander Afrikaanse organisasies verleen. Hierdie strategiese posisionering van die beweging was waarskynlik daarop gemik om wye erkenning en steun vir die beweging in Afrikanergeledere te verkry (OB-argief, GR-stukke, Korrespondensie, 1940-04-12).

Die tweesydige karakter van die $O B$ het egter veroorsaak dat verskeie negatiewe aspekte die $O B$ se beeld in Afrikanergeledere beperk en nadelig beinvloed het. Die noodregulasies van die regering wat 14 dae na die oorlogsverklaring in 1939 uitgevaardig is, was beslis ' $n$ beperkende maatreël wat die $O B$ se funksionering aan bande gelê het. Die noodregulasies het onder meer 'n verbod op vergaderings geplaas, waardeur die OB se massa-optrede lamgelê is (OB-argief, KG-stukke, band 1, lêer 1, 1939-11-22).

Die uitlewing van die dissiplineringsdoelwit in 'n semi-militêre styl het tot gevolg geliad dat Die Vaderland die $\mathrm{OB}$ as 'n "leemetford-kultuurvereniging" beskryf het. Vir diè blad was die $O B$ 'n semi-militêre beweging en geen kultuurorganisasie nie (Die Vaderland, 1939-08-15). Die Engelse pers het uit die staanspoor die semi-militêre inslag van die $O B$ onder verdenking probeer bring deur die beweging as ' $n$ militêre of politieke organisasie te bestempel Die OBoptogte is as "childish display", "showing off" en "heil a la Hitler" veroordeel (The Friend, 1939-03-04). Volgens die (ape Times het die OB hom as 'n kultuurvereniging voorgedoen, maar die beweging het in der waarheid 'n staatsgreep met 'n diktatorskap beoog sodra die regte oomblik sou aanbreek (The Cape Times, 1940-09-18).

Die dissiplineringsdoelwit het veroorsaak dat die OB-byeenkomste in dié tydperk met agterdog bejeën is. Die verbod op driloefeninge en die dra van OB-uniforms en kentekens deur die owerheid het gevolglik die dissiplineringsdoelwit van die OB byna onmoontlik gemaak (Van der Walt, 1944:46, 47). Bowenal het die Stormjaers met dade van geweldpleging die $O B$ se pseudo-kulturele beeld 
Die kentering in die kultuurbeeld van die Ossewa-Branctwag, 1939-1940

versterk. Hierdie dade het nie net die kultuurbeeld van die OB benadeel nie, maar ook veroorsaak dat baie kultuurgeoriënteerde lede onaktief geraak en uit die beweging bedank het (OB-argief, N.G.S. van der Walt-versameling, Dagboek, 1945-07-11; Hancock, 1968:338).

Die Grootraad het ook deur sekere besluite die kultuurtaak van die beweging beperk. Hierdie hoogste uitvoerende liggaam van die OB het in Julie 1940 die beweging se werksaamhede verbreed. Dit was nie die kultuurtake wat vermeerder is nie, maar die vryheidstrewe en politieke doelstellings van die beweging wat die Grootraad vir die eerste keer in die konstitusie geakkommodeer het. Hiermee het die Grootraad die dualisme tussen die kulturele en politieke aktiwiteite bygelê deur dit as doelstellings naas mekaar te stel (OB-argief, GRstukke, Die Ossewa-Brandwag konstitusie, s.a.: 1, 2).

Hierdie veranderende doelstellings en die oorlogtydse omstandighede het veroorsaak dat die $O B$ se vryheidsmotief die beweging se hoogste prioriteit geword het. Die sentrale tema van die voordragte op die OB-byeenkomste, wat as gevolg van regeringsdruk hoofsaaklik as braaivleis- en sportbyeenkomste gereël is, was vanaf Julie 1940 onmiskenbaar republikeins (Die Burger, 1940-1026). Selfs die konsepkonstitusie van die beoogde Boererepubliek, wat gedurende September 1940 deur lede van die Transvaalse Beheerraad gepubliseer is, het die republikeinse motief in 'n nasionaal-sosialistiese gees geopenbaar (Die Burger, 1940-09-23, 1940-09-25; vgl. Moodie, 1975:215).

Die invloed van die Nasionaal-sosialisme op die gewone OB-lid moet egter nie oorbeklemtoon word nie. Hoewel OB-lede op grondvlak op 'n populistiese wyse die oorlogspoging teengestaan en die totstandkoming van 'n republiek gepropageer het, het hulle nie verhewe ideologiese doelwitte in hul aksies gesien nie (Louw, 1990:27).

Die gebeure na 4 September 1939 het dus veroorsaak dat die OB van sy oorwegend kulturele optredes afgesien het (OB-argief, KG-stukke, Wat is die OB? - 1941-08-5-7). Die kulturele doel van die OB het, volgens die konstitusie van Julie 1940, uitsluitlik om die eenheidsverwagting en die dissiplinering van die Afrikaner gewentel (OB-argief, GR-stukke, Die Ossewa-Brandwag konstitusie, s.a.:1, 2). Die doelwitte van die beweging is tydens die eerste Laertrek van OBoffisiere gedurende Oktober 1941 gewysig, omdat die $O B$ tot 'n algemene selfstandige volksbeweging omvorm is (OB-argief, P.J. Nienaber-versameling, 1941-10-13, 14). Hiermee is die doel en strewe van die OB verander. Die klem is van die suiwer kulturele na die staatkundige terrein verplaas (Van Heerden, 1972:123).

Hierdie klemverskuiwing van die OB se doel en strewe ná Julie 1940 het veroorsaak dat die beweging se aktiwiteite in ' $n$ toenemende mate gemonitor is 
P.J.J. Prinsloo

deur organisasies in Afrikanergeledere soos die HNP of V, die FAK en RDB. Die gewysigde strategieë in OB-geledere het gedurende 1941 tot 'n verhoudingskrisis tussen bogenoemde Afrikanerorganisasies gelei (Roberts \& Trollip, 1947:80-83).

Dit was egter die wrywing op politieke vlak wat die OB se kultuurbeeld die meeste beperk het. Die politieke motief van die $\mathrm{OB}$ het in ' 1 wedywering met die HNP of V ontaard (Van der Walt, 1944:24, 25; Thom, 1980:103). Die HNP of $\mathrm{V}$ wou byvoorbeeld by die Afrikaner se kulturele aspirasies betrokke wees, terwyl die OB ook die Afrikaner se politieke ideale wou ondersteun (Hancock, 1968:369). 'n Politieke terreinafbakeningsooreenkoms was dus noodsaaklik om hierdie botsende belange te koördineer. Hierdie koordinering het aan die einde van 1940 op die sogenaamde Cradockse samewerkingsooreenkoms uitgeloop (Die Burger, 1940-10-31) - 'n ooreenkoms wat soewereiniteit vir elke deelnemende organisasie gewaarborg het (Van Heerden, 1972:191; Malan, 1959: 188).

Hierdie gebeure het veroorsaak dat die $\mathrm{OB}$ se kultuurbeeld in die volgende ontwikkelingsfase op die agtergrond geskuif is, ondat die Cradock-ooreenkoms inderwaarheid die beweging as republikeinse volksbeweging erken het (OBargief, J.H. Coetzee-versameling, 1941-10-01).

\section{Die $O B$ as republikeinse volksbeweging}

Watter beeld kan teen hierdie agtergrond van die $O B$ se kultuurdoelwitte gevorm word? Ten spyte van die vele organisasies wat in die Afrikanergeledere werksaam was, het 'n kragdadige organisasie waarin die volk se nasionale aspirasies beliggaam is, ontbreek (Die Volksblad, 1940-10-31, 1940-11-06). Die $\mathrm{OB}$ wou daarom as 'n omvattende volksorganisasie ontwikkel (Die Burger, 1940-11-13, 1940-12-11).

Dit was die Cradock-ooreenkoms wat die Afrikaner organisatories moes koördineer en wat die werksterreine van organisasies in die Afrikanergeledere herafgebaken het. Na hierdie ooreenkoms is die OB se werksaamhede op die algemeen nasionale gebied gespesifiseer. Die taak van volksamesnoering is aan die $\mathrm{OB}$ opgedra. Hierdie samesnoering het die hoër geestelike belange van die Afrikanervolk geraak - ' $n$ faktor wat die vername status van die $O B$ in die geledere van die Afrikanerorganisasies benadruk het (Die Volksblad, 1940-1101). Op hierdie wyse het die $O B$ 'n bondgenoot van alle Afrikanerorganisasies geword (Thom, 1980:101; Van der Walt, 1944:29).

Dr. D.F. Malan het verklaar dat hy die OB van harte steun, omdat dit sy idee van 'n omvattende volksorganisasie verwesenlik het (Die Burger, 1940-10-31). Die bewierokingsproses van die HNP of $\mathrm{V}$ het aan die getalryke $\mathrm{OB}$ ' $n$ kunsınatig 
verhoogde status in Afrikanergeledere verleen (Van der Schyff, 1974:566). Die steun wat die $\mathrm{OB}$ van hierdie party geniet het, het aan die leiersfigure van die $\mathrm{OB}$ ' $n$ valse konsep van die beweging se kragdadigheid gegee en dit was indirek vir die $\mathrm{OB}$ se val verantwoordelik.

Die OB het teen die einde van 1940 'n indrukwekkende statuur gehad en is as die belangrikste landswye beweging bestempel wat die Afrikaner tot nog toe gehad het (Die Volksblad, 1940-11-30). Die kulturele bestendigers se beeld in die beweging was nog sterk, maar dit was tog duidelik dat die OB as volksbeweging reeds 'n metamorfose ondergaan het.

Laas is deur die nuwe ontwikkeling in die beweging op die agtergrond geskuif. Hy het die veranderde doelwitte van die OB sterk veroordeel. Dit was egter ook duidelik dat hy sy beheer oor die beweging verloor het en daar is druk op hom uitgeoefen om te bedank Laas se Vrymesselaarlidmaatskap het ook die ontevredenheid in OB-kringe laat intensiveer (Van der Walt, 1944:23, INEG, J.F. van der Merwe-versameling, leer 22/1/1/3, 1940-06-05). Hy het gedurende Oktober 1940 as kommandant-generaal van die OB bedank en verbitterd van die toneel verdwyn (OB-argief, GR-stukke, Notule, 1940-10-03). Gedurende 1941 het Laas 'n nuwe beweging, die Afrikaner Volk, gestig (OB-argief, C.M. Immelman-versameling, s.a.)

\section{Slot}

Intussen was die $\mathrm{OB}$ se duisende lede met hul onaflanklikheidstormloop besig (Die Volksblad, 1940-11-28). Vir die OB, as republikeinse volksbeweging, was die politieke implikasies van hierdie stormloop nie sonder betekenis en gevare nie. Die beweging se nuwe kommandant-generaal en peetvader van die beweging, dr. Hans van Rensburg, wat as 'n aanhanger van die Nasionaalsosialisme beskou is, het vanaf sy eerste openbare buiging sedert Januarie 1941 die $O B$ midde in die politieke stryd betrek. Hy sou die pseudo-kultuurdoelwitte van die $\mathrm{OB}$ in ooreenstemming bring met die veranderende prioriteite wat die leiersfigure vir die beweging gekoester het.

Op 13 Oktober, die eerste dag van die Laertrek van OB-offisiere, het Van Rensburg verklaar dat die $\mathrm{OB}$ as 'n kultuurorganisasie gestig is. Volgens Van Rensburg het die Afrikanervolk meer in die beweging as slegs 'n kultuurorganisasie gesien; daarom het die $\mathrm{OB}$ tot 'n kragtige volksbeweging ontwikkel wat die vryheidsideaal van die Afrikanerdom aktief nagestreef het (OB-argief, KG-stukke, Toespraak, 1941-10-13).

Hierdie opvatting het 'n pragmatiese beleidsontwikkeling wat reeds in die $\mathrm{OB}$ aanwesig was, bevestig. Dit het veroorsaak dat die $O B$ se kulturele doel en strewe en daarom ook sy grondslag, beleid en konstitusie saam met die beweging 
se veranderende prioriteite ontwikkel het. Die klem is van die kulturele na die staatkundige terreine verplaas (Van Heerden, 1972:123).

Die bovermelde aard en kultuurtaak van die OB gedurende die Laastydperk het ook op 'n treffende wyse die onderliggende geestelike stroming in die ontwikkeling van die Afrikanervolk blootgelê. Dit was die Afrikaner se ideologiese soeke na identiteit wat in 'n georganiseerde nasionale beweging gemanifesteer is (Van Jaarsveld, 1981:20; Meyer, 1940:132). Die OB het by monde van Van Rensburg 'n groter rol in die nasionale beweging gesoek - 'n faktor wat tot 'n nuwe ontwikkelingsfase vir die beweging gelei het (Van der Schyff, 1991:48-77).

\section{Bibliografie}

\subsection{Instituut vir Eietydse Geskiedenis (INEG), UOVS}

\subsubsection{I.M. Lombard-versameling}

Lêer $1 / 3 / 2 / 1 / 1$ : FAK, notule van vyfde kongres, 1939-07-05

Lêer $8 / 4 / 1 / 1 / 1$ : FAK, program van aksie, s.a.

Lêer $2 / 3 / 1 / 1 / 3$ : FAK, die koordinering van Afrikaanse liggame en organisasies, s.a

\subsubsection{J.F. van der Merwe-versameling}

Lêer $2 / 2 / 1 / 1 / 1$ brief A Benadé (sekre. OB-kantoor) aan J.F. van der Merwe, 193910-27.

Lêer 22/1/1/3: brief A Benadé aan Japie, 1940-06-05.

\subsection{Ossewa-Brandwag-argief, $\mathrm{PU}$ vir $\mathrm{CHO}$}

\subsubsection{C.M. Immelman-versameling}

Konstitusie van "Die Afrikaner Volk", s.a

\subsubsection{Gebiedsleidingstukke}

Gebied A, Wes-Kaapland-stukke, Die Ossewa-Brandwag: doel en strewe, s.a

\subsubsection{Getranskribeerde onderhoude}

Botha, MW., bande 160, 161

Coetzee, J H., bande 76, 77

Grobler, M.S.F., band 103

Pohl, A S, band 75

Robinson, H.M., band 43

Roode, J B , bande 168-171.

Stegmann, B.Z., bande 135-137

Van Rensburg, W.J., bande 99, 100

Wagner, J, band 153

\subsubsection{Grootraad (GR)-stukke}

Korrespondensie: brief ds S.J Stander aan Laas, 1940-04-12. 
Korrespondensie: brief J.A. Smith aan Laas, 1940-01-12.

Korrespondensie: brief J A. Smith aan Laas, 1940-04-02.

Korrespondensie: brief van Sekretaris aan J F van der Merwe, 1940-01-23

Korrespondensie: brief van Sekretaris aan M P A Malan, 1940-02-10

Notule, 1940-10-03.

Notule, 1940-12-10, 11.

Ossewa-Brandwag Jaarboek, jg. 1, 1949

Die Ossewa-Brandwag konstitusie, s a

\subsubsection{H. van Rensburg-versameling}

Band 4, lêer 35: toespraak, Fauresmith kommandodag, 1938-09-07

\subsubsection{J. de W. Strauss-versameling}

OB-bevel, 1940-11-08

\subsubsection{J.H. Coetzee-versameling}

Du Plessis, L.J., Die Afrikanereenheidskomitee en die geskil tussen die OB en die HNP of V, 1941-10-01.

\subsubsection{Kommandant-generaal (KG)-stukke}

Band 1, lêer 1: brief van Sekretaris aan J. Swart, 1939-11-06

Band 1, lëer 1: brief van Sekretaris aan J. Swart, 1939-11-22

Toespraak, Pretoria, 1941-09-11

Toespraak, Laertrek te Bloemfontein, 1941-10-13

Wat is die OB? ('n lesing deur assistent-KG, O.L Nel, tydens 'n Natalse offisierskamp), 1941-08-5-7

\subsubsection{M.S.F. Grobler-versameling}

Program, Dingaansdagfeesviering, Pretoria, 1940-12-15, 16.

\subsubsection{N.G.S. van der Walt-versameling}

Korrespondensie: brief J V.W de Vries aan N.G.S. van der Walt, 1939-05-10

Van der Walt, N.G.S , Dagboek, 1944-04-30, 1945-07-11.

\subsubsection{Noodhulp}

Korrespondensie: brief van Sekretaris aan B.C. Neveling, 1940-07-09.

Korrespondensie: brief T Wassenaar aan Sekretaris, 1940-04-12.

\subsubsection{P.J. Nienaber-versameling}

Notule van eerste laertrek, Bloemfontein, 1941-10-13, 14

\subsection{Ander bronne}

BEALS, R L et al 1977 An introduction to anthropology, 5th ed. New York MacMillan.

BUTLER, G. 1961 The development of a South African national character. Forum, 10(6):9, Oct

CRONJE, G. 1963 'n Sosiologiese beskouing oor die Westerse kultuurproblematiek in Suid-Afrika. Herizog-Ammale van die Suid-Afrikaanse Akademie vir Werenskap en Kuns, 12(16) 32, Des 
P.J.J. Prinsloo

FOURIE, L.M 1987 Die Ossewa-Brandwag en Afrikanereenheid, 1939-1942. Potchefstroom : PU vir CHO (D Litt -proefskrif)

HANCOCK, W K. 1968. Smuts, vol. 2: Fields of force, 1919-1950. London Cambridge University Press

KOTZE, C R s.a Die Ossewa-Brandwag: sy ontstaan, ontwikkeling en botsing. Bloemfontein : Nasionale Pers.

LOUW, S 1990. Discourse theory. Afrikaner nationalism and the Ossewa-Brandwag. Stet, 6(3):27, Nov

MALAN, D F 1959 Afrikaner volkseenheid en my ervarings op die pad daarheen. Kaapstad : Nasionale Boekhandel.

MEYER, P J, 1940. Die Afrikaner. Bloemfontein : Nasionale Pers

MOODIE, T D 1975. The rise of Afrikanerdom: Power, apartheid and the Afrikaner civil religion Berkeley: University of California.

MOSTERT, D J.J 1940. Gedenkboek van die ossewaens op die pad van Suid-Afrika. Kaapstad : Nasionale Pers

PELZER, A N. 1979. Die Afrikaner-Broederbond: eerste vyftig jaar Kaapstad : Tafelberg.

PIROW, O s.a James Barry Munnik Hertzog. Cape Town : Howard Timmins.

PRINSLOO, P.J.J. 1983 Kultuurbeeld van die Ossewa-Brandwag, 1938-1952 Potchefstroom : PU vir CHO (M A -verhandeling.)

ROBERTS, M \& TROLLIP, A.E G 1947. The South African opposition, 1939-1945: An essay in contemporary history. Kaapstad : Longmans \& Green.

SCHOLTZ, G.D 1974 Dr Hendrik French Verwoerd, dl 1 Johannesburg: Perskor

STEWARD, J H 1955. Theory of culture change: The methodology of multi-linear evolution. Urbana : University of Illinois Press.

SWART, M J \& GEYSER, O 1979. Vyftig jaar volksdiens: die geskiedenis van die Federasie van Afrikaanse Kultuurvereniginge, 1929 tot 1979. Johannesburg Federasie van Afrikaanse Kultuurvereniginge

THOM, HB 1980. D.F. Malan. Kaapstad : Tafelberg

VAN DER SCHYFF, P.F. 1974 Eric H Louw in die Suid-Afrikaanse politiek tot 1948 Potchefstroom : PU vir CHO (D Litt -proefskrif)

VAN DER SCHYFF, P F. red. 1991 Die Ossewa-Brandwag: vuurtjie in droë gras. Potchefstroom : Departement Geskiedenis, PU vir $\mathrm{CHO}$

VAN DER WALT, A JH 1944 'n Volk op trek of 'n kor geskiedenis van die ontstaan en ontwikkeling van die Ossewa-Brandwag Johannesburg: OssewaBrandwag.

VAN HEERDEN, F J. 1972. Nasionaal-sosialisme as faktor in die Suid-Afrikaanse politiek, 1933-1948 Bloemfontein: UOVS (D Phil-proefskrif)

VAN JAARSVELD, F A. 1981. Wie en wat is die Afrikaner? Kaapstad : Tafelberg.

VAN RENSBURG, J F.J 1956. Their paths crossed mine: Memoirs of the Commandant-General of the Ossewa-Brandwag Johannesburg : CNA

VATCHER, W.H. 1965. White laager: The rise of Afrikaner nationalism. London Pall Mall Press 